かたれ口ず四次て資特れかで

ヘ。ぞ、れ $\bigcirc$ の本質、らあ都

都現れキに、よる主の論繰る。市

市在別ンも鈴らと義本議り返こ農

村わな都に杰述う展的対しれ村

落れ原市見采心社開展象問まの

のわ理的え郎て会が開と題で構

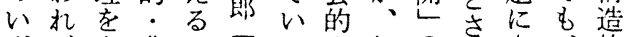

ずがも農よ氙る現都堛れさ、的

れ当つ村 5 本実市王るれれ関

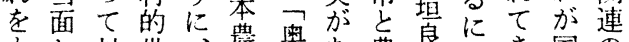

もし対世、垚奥あ農良到き国の

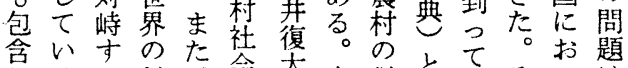

七るる対事会郎中従来称々そしては、

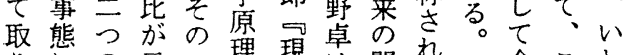

りにの示い理現は閵るそ机こわ

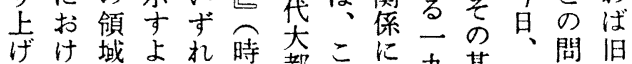

げけ域よ机時都こに都九基再䦗旧

なると 5 に潮䒾う著五基再題く

わ地しに社論しい吾にびはて

け域研都用一有現変以は年はさし

に研市さ九有実化降口問まい

いは究とれ四斐にを降戦題ざ問

か、さ村てつ閣注まの後がま題

なそ机落いし自たわ段注なの

いのてはるの一しらが階目角一

汃なぞ、九てし国のさ度つ

つ採じル大とし社わをたよ村に

て用めト都しょ会それめ関まう落りち

、にて的杨てう全のるぐ連さなの、゙

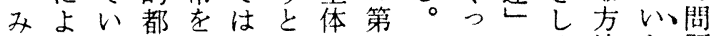

ずっる市中、すの一のく法よ題

かてこ地核例るなの

ら急へ域とえ方方

都速とつすば法に向

市に進最る山で都は

生変ん近大本あ市都

活华でで都登る。豊市

なし、は市は。農䓪次

かまが、㞧々拝をな

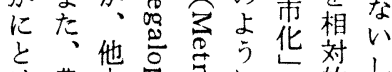

け農方仿客に店的し

质豊㤩述鍵位統

みは農と忥鍵位統

つ兼は番いをい念直機

あ業高方るとしけ関

る豊す菜た次た両を

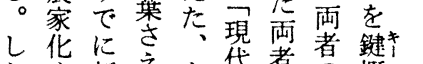

た货に新忘よ代者者鍵

ことい用広お関連と

てと術机なて把把て

都よのはべは握握

、解、染いと

今明こなよな

日、がさ深っ

研わ新る尗少き

究れた㤂たて

はわ閏き関、い

三机閴で連る。

のと状あるとこ、

方先加占 况

向て、七え新

にの拵傍たない

以題市点め閔

てな展な箬わ題、

開の゙落者わ状、

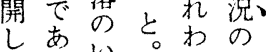

てる机な

いる゙よ机な

るか、解で

よ そ

に解まと泟

古

城

利

明

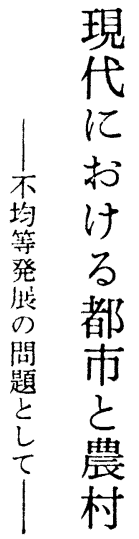

\title{
特
}

論

当

け

都

而

農 


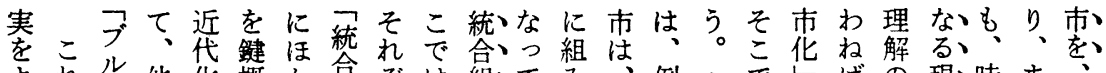
よれル他化概か㖪ぞは組てみ、例までしばの現時ま

りに南に念な関れ農織さ入全えたはをなた象代た農

深対寻で伴とら関は村と、たれ体ば農軸らめは錯、村 刻して的のなしなる全はのから社矢只村になに、誤特と、 にて自都うたいを体都構られ会崎統はしいは日の定の、 認、国满都都。軸社蒂造、、、会武合、たの、本、感の対、 め第祭と市市こと会を関、近全大年機都地で新の、壳都立、

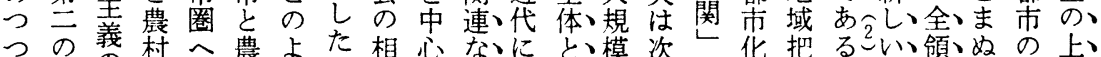
つの義村へ農よた相心なにと模次化把るこい領ぬの上 、方現のの村う都詨とし近の化のを握し視域がみで、 第向䒫対農のに市的しにくく有吉よ鍵るで傍野をいれに取 の は版立村構みに地たはな機るう概地あ傍においな視り、 方都に格の造てよ域統理る的ほに念域る点立おい野上 向都格つ関くると合解、ほ構ど述と圈こ荁つつ状をげ、 向市差包連る農な機し、ど造大心゙し内と息こて、勢限る

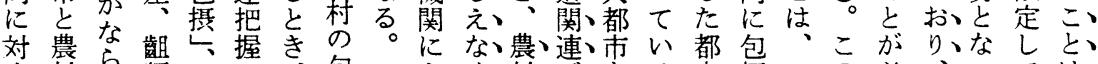

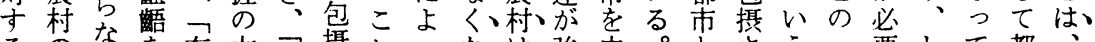
るのな童有方都攝れつないは強中。とさうて要して都

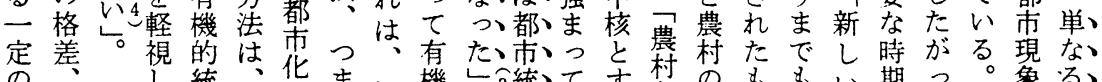

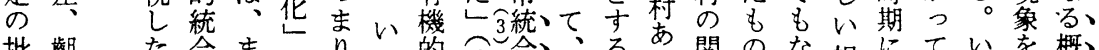
批龉た合まやりり的傍合、るる関のな視にていを概

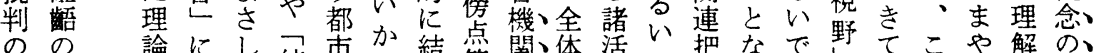
のの論にし統市が結点関、体活い把なで野てこや解の、 上社で焦く統化え合茟やの動他握つあがいの、揓、 に会あ点社嘰のれさ者全一の地とてろかる 問都る戯、

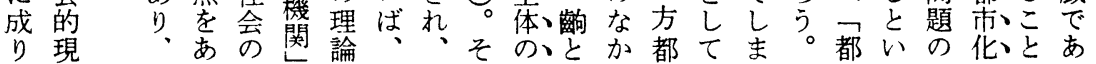

域はう提農え的のけ義都捨に注違にぞ左な活関家がた と、鍵起村る現理ての市象対自えお㣗衛く上連含つ 、云概さに。実論把歴とにししいけ門、のな合まて 人物念れまそのは握史農よて、前る機か鈴連いしれい 的的宁てたう前、さ的村っは第近文閏ら斜しとるる

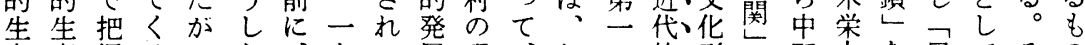
産産握るるた、九て展現、わの的形野太を民てその のをしの地現そ五い段象一が方農態を卓郎媒族とので 担によは域実の五な階的般国向村の通らか文ら第

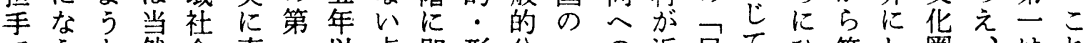

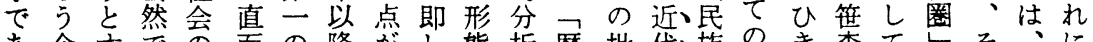

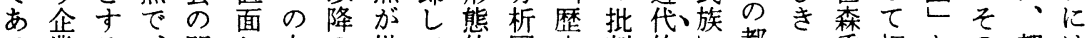
る業る、問し方の批て的図史判的都つ秀把との都は 家活方そ題て向い判、関式的と都的市が雄握い相市 族動法こを、批わさと連と条な市特とれらしう互とお ををがかと地判ゆれりの類件っに誓農るによて間農お 中中登らり地のるてわ把型のた包を村理ひうあの村ま 心心場第あ域鋭年いけ握を下。攝主の論きとる関をか ととし云げ社鋒高る経に構でしさ張支がうすす連的に しすてによ社は度の済と想のか机等配そがる定を聚い

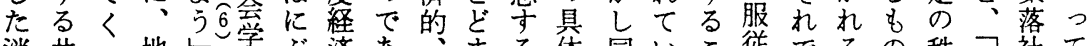

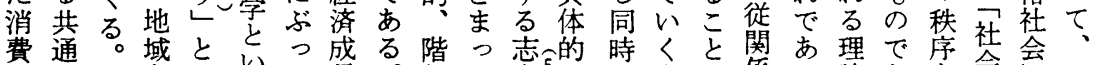

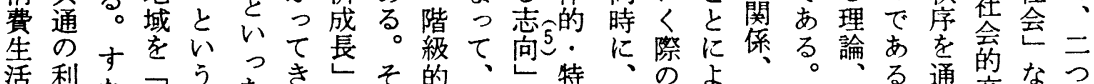

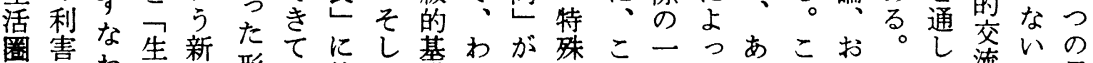

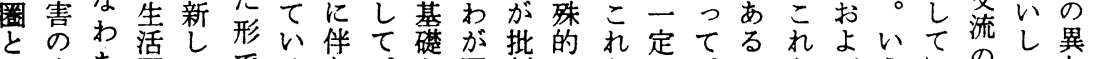

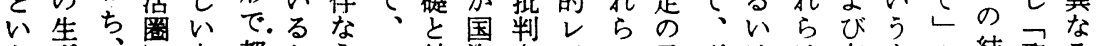
う年、方都からこ結資さべの矛形はは有まの結聚る 三るそと法市に社れび本れル理盾こ両そ賀で節落方 範れいが々会らつ主、の論にそ者れ喜も生機的法 
編エと階をばでる军の再産決せとるが跛の国をるの

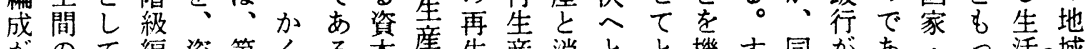
がのて編資第くる本産生産消とと機す同があ.方活域 ᄀ不々成本至し。学消産の费導ら械な時問る地た圈的

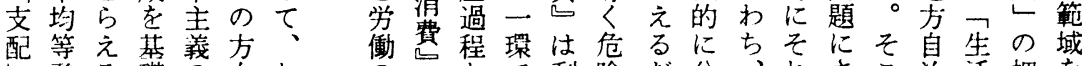
以登る礎の向わののと茢険だ分机さこ治活把を

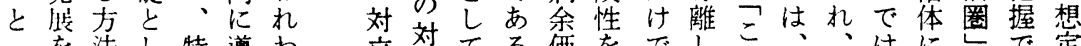
フを法し特導わ立対てる価をでしの゙てるはに定 連軸でてに艻れ 㷼とあ、産れは、 のしる。先業ざ諸る第 対把そか部を一 立握こら門えの のさでユ間な方 基れは支のく向 礎、都配不なへ をそ市均るの 構れとと等。批 成に晨発す判 し基村連庭なを 、基の荐にわ徽 ぞく檴基 ち、底 こ市造と方場的がくそ ら関関对市礼て こ倸連立場は、 のとは守関、く 都階、る倸地な 市級農場と域ら

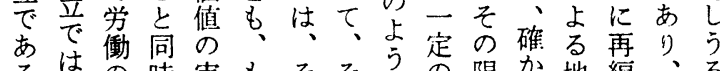
るは㤎時実もそそう限か地編、る こな被に現っの扎限りに域成飞こ 々く撚過て根を経界で現計さこと

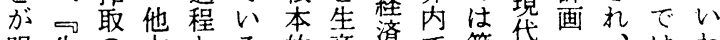
明生の方とる的産済で第贷・的わ か産過で生と程は活い問般社批の再社そ都れ で消の、手わ題と会判方編計ひと あ費二労段な产生生向成画ず、農

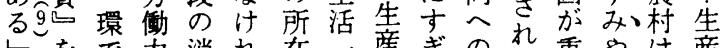
しをで力消れ在文産ぎのれ重やは産 とつあの費ばを般とな批都視格新と いらる消過な息と生い判都さ差た消 つぬ。費程ら失い活こと市机のに費 たく批た過とな程し、形物㤎を農る、是びの

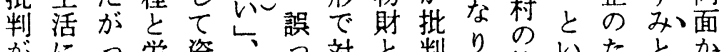
がにつ労資、つ対と判り格いたとか 之おて㗢学本た立人さう格うめ格ら

に制要はつ両問 业の、約都ち智者題さ

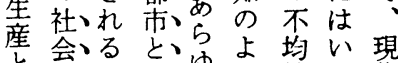

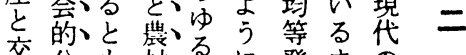
交分毛村登に発まの 通業、以と涨、廍え独 の の、えの、展 $\mathrm{K}$ のに点

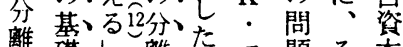
離礎、基離、商、題そ本 都傍あ゙品ルクにの主 都市点る。交原い礎、段

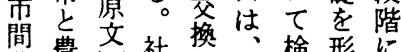
分唇已社筷、検形に 業村と会よ古討成お の柴のよ典ししけ フ忘全て経てたる 大離た経媒済お産都 で学媒学き業市 業あす史さの理い資農 下っなこれ論。主村 でこち対公念段不 の分、立分念頭階均 自業私立業に頭等 然は的運のお お発 成さ所動基き河展 長ら有、に礎つるの
るる。代に最都さにによし離こと兄 そ本いのとてかっう両と符 し主て主農、なてあ者がの て義若導村本ら、るの示局 まの干方の稿な既資間さ関 た構の向構のい述本にれ係 造批々造目。の主おるの わ的判み的的第義け.の発 れ危をら関は一がるで展 わ機試れ連、 ど対あが れのみる第こ立る資

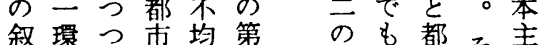
述で、と等等方つ市そ義 はあそ農発の向れにれ的 るる村墏方をてよは危 主こをのの向根いるす機 とと通機問を継的同树と釀 て示的と承に伴 $の$ 、成 こ都関しし批者㩁つ寸 のう市連てつ判な取農る

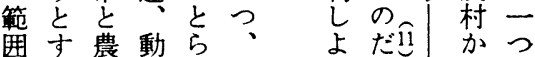
内る村的え現 $5 \longleftarrow こ 5 の$ にとの均代とをれの条 限こ問衡あにす示は都件 定ろ題のわおるすす、市で さにが理せけ方こ発のあ れあ現論てる法と晸分る 
展条主り、転さ体現盗ち、上、論示り、問造なは産治つ的

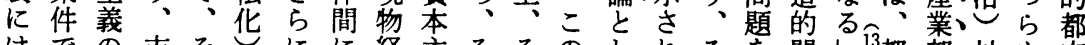
はでの市そいにに経主そそのしれそを関し都部対ぬ市 蓄あ発場の々生商済義このレてたの連敦市門立いに 積り、展の結々産品の経で要 | 提再国先を傍川別立て替 は、に大果い者吕状済は旨二起生内至点なな矛、方

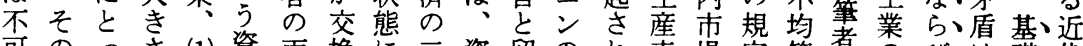
可のっさ(1)資両換に三資留の机表場定等者鼻び、礎、代 欠こては李極さあっ本意理て式形を発と傮に展で的 でとは社市素分机るの主点論い川成基展さ位地開あ産 あに、会場義解、第二義を自る実川礎のさと域さる業

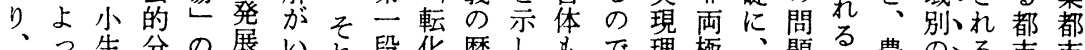
そて生盆の概のっれ段货糜しも、て理極、題る。農のる市市

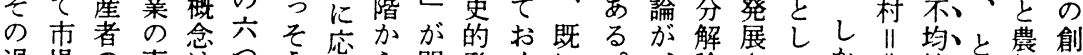

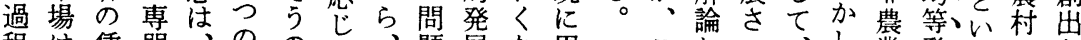
程 は貨門、ののて、題展な周 で発労化社段市市社とにら知 生展㣫と会階場場会さおばの

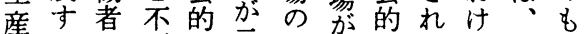
手る公可分示搪搪分、る次の 段至の分業さ势業六現ので 段市転での机をしが人物よあ 産(引)化あ概るすも第ら生済にが 部資川こ忞でら第わ産な

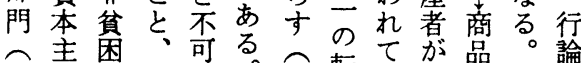
第義华(2) 分。第転てがす氉す諞

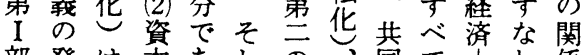
部発は本あしの同て】わ倸

こおせ、ᄂ、業愽うとと

のよた体、の展ののい 問びの采立立で物う 題之は的儿衣特あ゙物形 をの比行徵る的で 解市! 矿々 莳場 I 示は机守そ精開 る発的元都従資放神る 展レい市属本故的艻

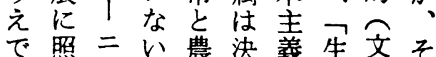
の応ン。村定社産化机 基しでこの的会力. 礎ててあの構とでの政を

本民るるり的れし展を市るこえ部発とと口矛い門 線中。と関にてとを抜につとな門展実、農レ盾う年

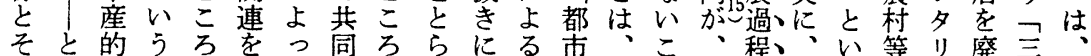
のそ生まと明て体でえし農的ことし等レうの交う消 起の産でしら、の、るて村諸のをた、1コ住|粚の費 動両者もてか小崩ここ、の関不示が工二三民結手

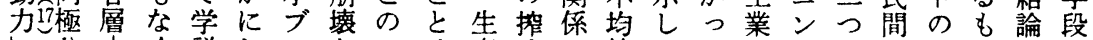
分|く説しルとレは産取の等ててとはのの欲の先生 が解、学て涪、で力農登い都農以指交望でと産 求の小そ構い、的た二き格を树展る市業上摘通水なと、部

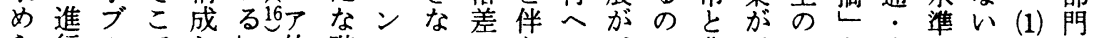

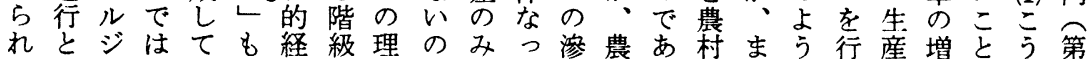

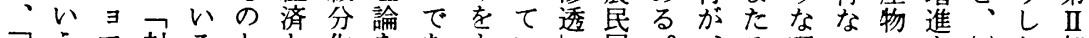

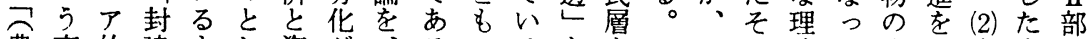

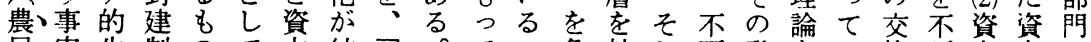
氐実生制のて本結可。てこ条軸し可発をい換可本本し 層の産のに高主果共しと件とて避展展るに避主主に な者解、く義し同てでと方、的に開のよ的義義拨 のかと体い評発て体、あしるそに照すでっにのの越 内にしのわ価達く内都る、少の不応るあて伴発発し

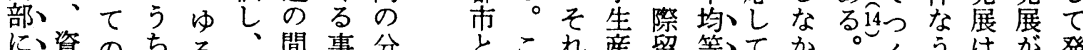

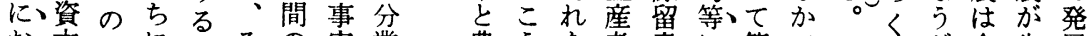
お本職に大その実業農う荐意に第で、りが全生展 け主人形塚杂歴を美禁し通層し発、I、

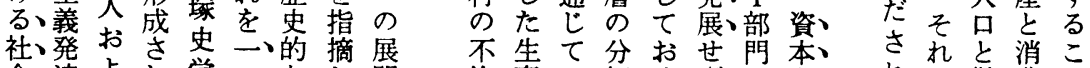

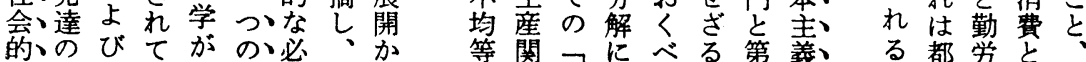
分、基農くあ拠然こら 等関 都よ 
的と掑きのわ思埸しのた門業証とか質だ等そ村彼、業、 不し取こででばわのた示そののさにも的と性の晳佊栄、 均てしのはあ発れ搪生唆こ不分れ注同ないと業相、発、

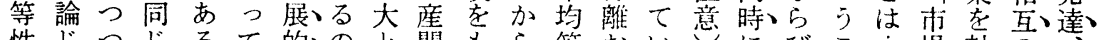
性じつじるて的のと関斿ら等おい心 にびこ

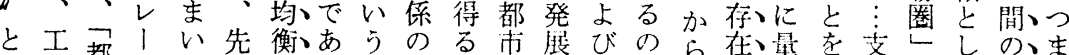

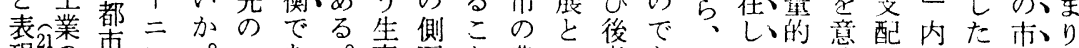

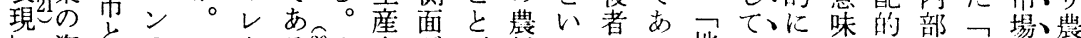

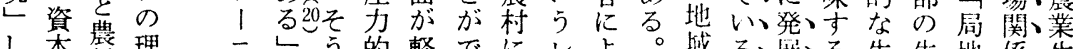

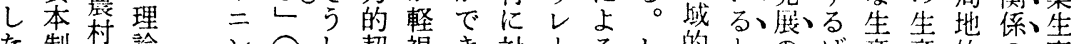
た制梦論ン詹し契視き対、るし的との、ば産産的の、産 も生とに的傍た機さるす二市た市い度か関箸市形加 の産矛依意点意にれのるシ場が場う合り倸部場成ら

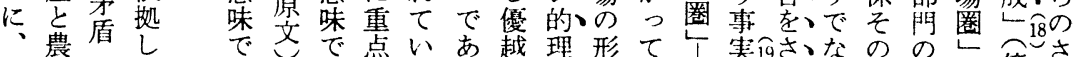

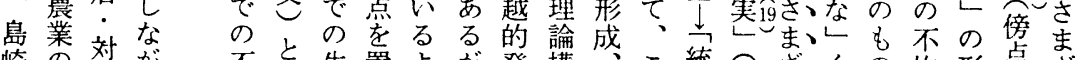
崎の立が不々生置よが発構成こ統傍ざくの均形点ざ

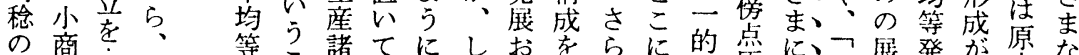

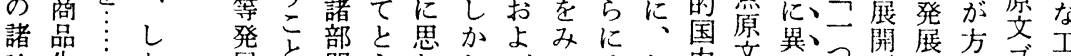

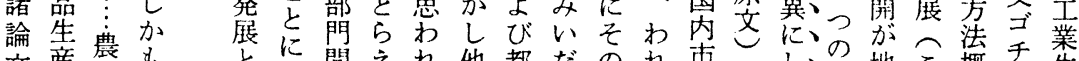

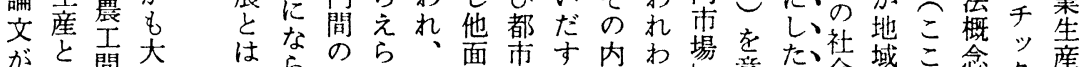

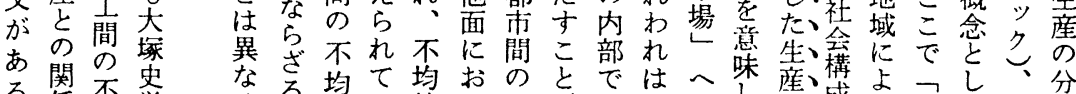

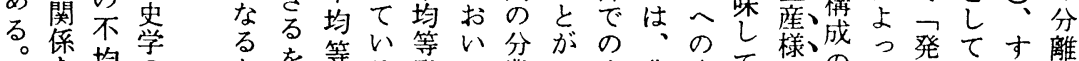

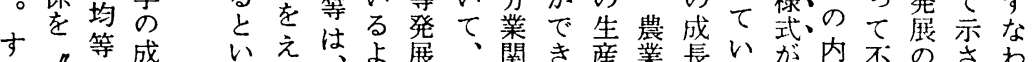
な構発果うないよ展関き産業長いが内不のさわ独

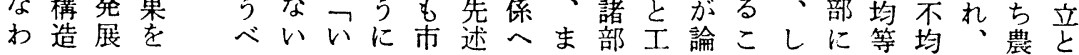

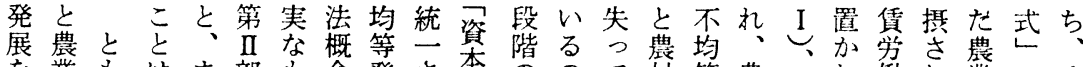

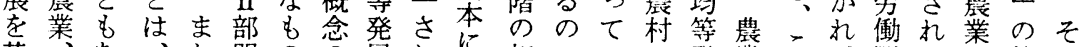

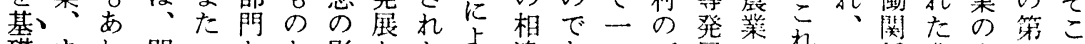

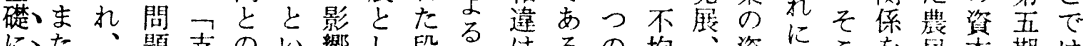
にた、題支のい響し段る非はるの均盗次こ圭医本期は

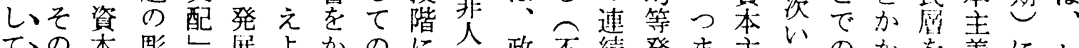

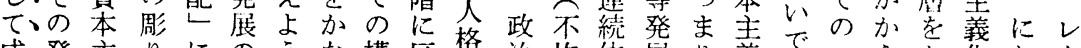

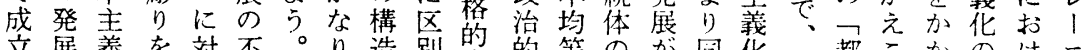
立展義を対不。り造別的的等のが间化つ都こかの忛二 すの社浅立均だう的さ变支発な、じが岪柿むえ特るン

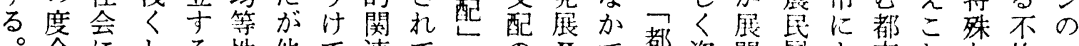

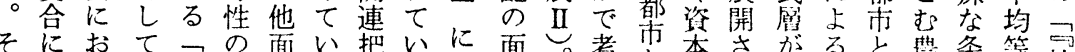

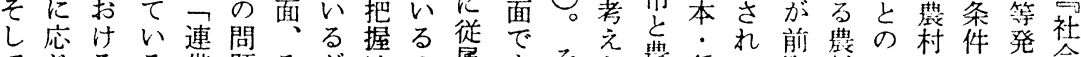

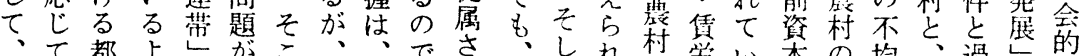

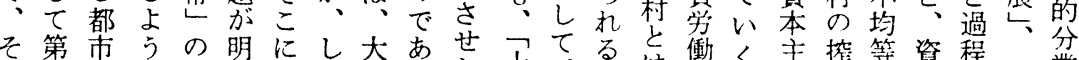

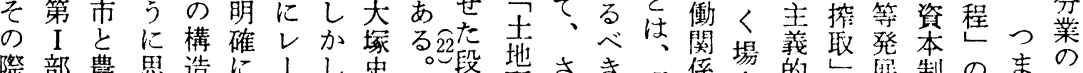
際部農思造に 、門村わ的位二よ学こ階乺ら段理を合ながが的下り完

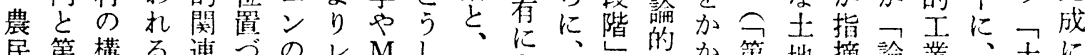
民第構る連亏のレ M ᄂ よ地摘論業、士に

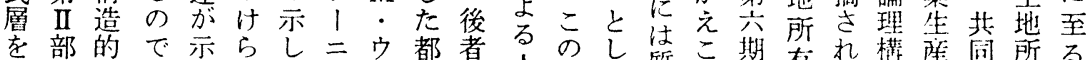

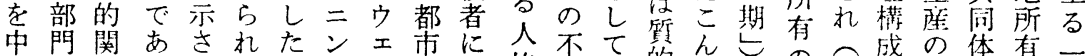

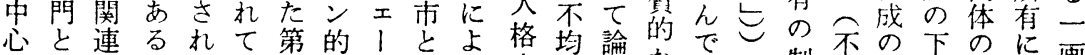

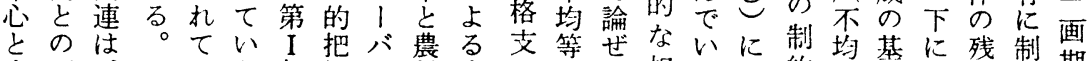

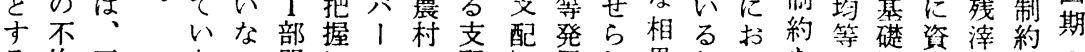
る均工ない門にのの配展れ異都けを発本にさ气 小等業いこと忠方不にをのてを市る離展に・包机表 
つと地を影での化そお検

いて域中響はも亦音九艻討と

は都とと六加世味世湖

、市ししな都ら娄紀わこまで

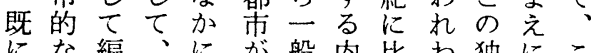

にな編にに㐌般内比わ独にこ

九格さ焉捸住会がてが段そ独

世をれ导し形現、三荷階れ占

紀帯る 命之態象質 $\bigcirc$ う $と$ と段

末ひに朶炛的世的世問対階

かつ至高結しな規紀き題立に

らつり秸て性定課がしお

三あ高果の格加と題い、け

○る登地地のらり存かそる

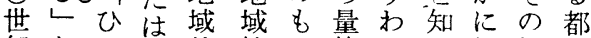

紀といる的社の的ける把批市

はさて岕居会へ現一手握判と

じれは严住在と象九がさ対桃

めて人导社ま転化三加象村

にいびき会す換へ○りつとの

かると芯はます、年をつな不

け。のす、寸る経代得ある均

てこ社壳そ自に済以てるて等

、引会』机芑至構降おかい発

Fし生とぞのし造きをる㩐

・た活呼机支り的は、た検諸の

テ傾はば大配、なつい討理問

ン向全れ都圈そ性都。し論題

ニに体る市・こ格市、、にを
発れとがら関のま生 馓をし、わ係㵠で産 の解な現れは取の者 問明が代、、不盧 =題しらにこ政は均の をてもお机治強等分 考い、けに的め性解 えくそる対にらをに なたれ都しも机支よ けめの市て近るえる れにみと自代。る ばはで蕽喾国そ条都 な、は村的家の件市 ら独尽となの基と的 な占くの労成礎な諸 い資し構衝立のり関 本え造者とう、係 主な的とそえこの 義い関農のに机農 段現連民下、在村 階帮はので都通へ のを、連の市じの 都あこ蒂地とて渗 市らうが方農古透 とわしあ支村都逶 曟したら配の市は 村てこわを支に のいと机通配よ一 不るをる辛・る定 均。基。て従農時 等そ礎だあ属村期

既ま述す象はもすて 体的鄙です全農し因費はと!

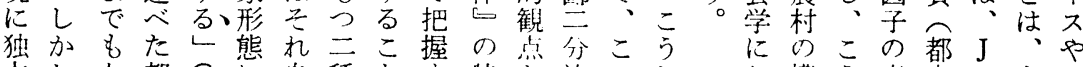

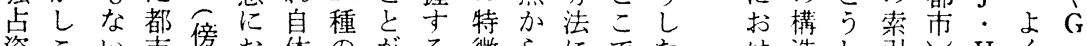

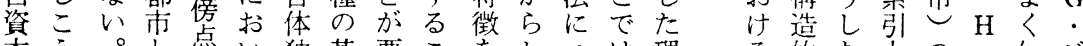
本 5 点い独基要こ在しつは理る的た力の・知 シ 主し農筆て自本請亡心てい行論 義た 村者との的さにそもて論の

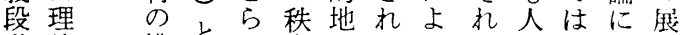

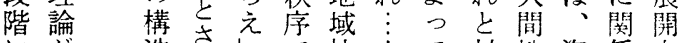
にが造さんで社!て対性資倸自 突展的れなあ会凹、照の本夺体 入開関てがるで都外的探主るに しさ連いら交市見場究義要つ てれ把た、とると的でのの点い いて 握点污して震であ一自をて たいにをかてと村はるつ闫指は た 対指も、しと否のと摘 そ一応摘両都てはる村場繁守既 れ九守し者市、、がとで栄るに

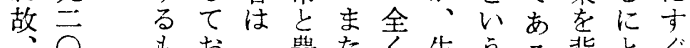

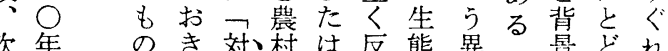

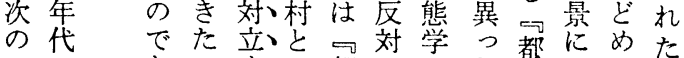

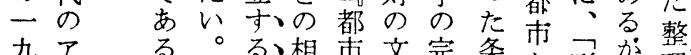

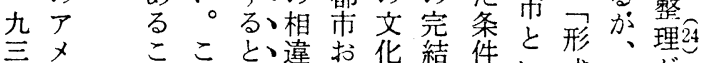
○リと机共喡な化結件い式まが 年力 はがにそび類を比う社ずあ 代は $は$ 調、の農型歨較社会、る に、うデ和現村を揚し会学都の 都関背理地 $\mathrm{v}$ ら ン 鄙連景論域・ れメ 三を起と的千てル 分上反し均卫Wが 法り映て衡 は る社 論あし主理ネと会 かげて張論ンこ関 らた、しとやろ倸 都 む最てしA 鄗のもいてて あ精 連は端た、ウり、神 続、的こあエ、構 法まにとる|ま造 論ず、もいバたの へもこ周は にそ側 のつの知工がの面 展て段の業、経加 開、階こ立生済ら にアにと地産過指 おメ求てに元摘 いリけあお農程し て力るるけ業にて で都都。る年つい あ市市し立といた ろ社とか地消てこ 
かつに村とうみ都もをェ体蹗析る落よつ開を早 かけ関はしまる方せ市まつのフと村視こ的こてさ相く

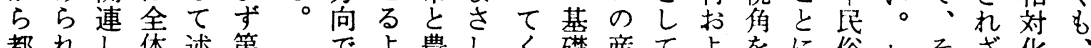
都れし体述第でよ農しく礎産てょをに俗わそざ化 市たあ社べー あう村くるを業把びうよ社れのるし都

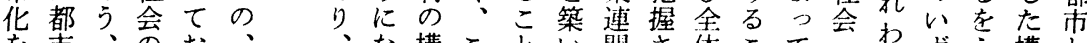
を市、会お、な構ことい関さ体こてふれわずえ構と 社化と近い都もる造のにての机社と、录れれな造農 会のい代た市う。的一ない均る会が現热はかく的村 会概う化も化 一そ関九るる衡の会で代高都上な ス念ものの概つの連五。こ分で棈き文完书のる機独 テはのなで念に発把 ○析あ造る明历関。能自 厶、でかあの批握年沙やる的のに号産係す的性

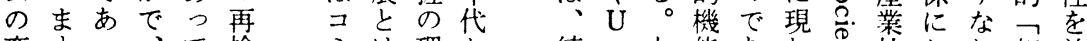
変すっ、て検ミは理か続. な能あわ岕社抄わ相前

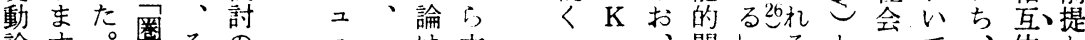

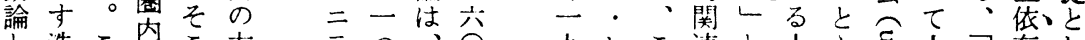

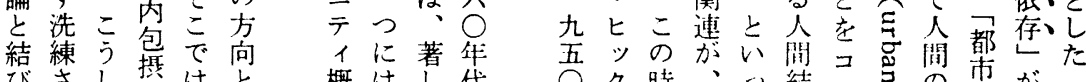
びさし热はと 机元福は、 る機会有述本 る機会譏よ稿 み化体的 5 がさの統にで あれ変合、第 ら、動合都一 わそとを市の れの結媒と方 るなび公農向

概はし 代 念都いに の市発か 再化成忛 検 概 之下 討 念 統 との合現 心再入代

う検 のに 方捨志お 向之向け でいをる ク時、”結ミ引の市が二

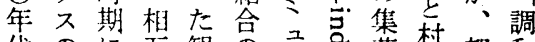
以帒のに率観の土基二吉落落都和 降会 $\mathrm{W}$ 存架本テ基形忘連に

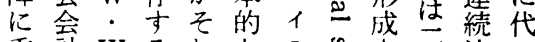
重計 $\mathrm{W}$ るれなの总さう法つ

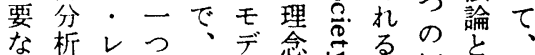
意等オのの都ル型さ怘極し二 味がン連市のととみでて分 を、千続と分み村てあ展法
の、ッので系地 要卜トコはの地 素交ミ都連関 に、換二市合連 適、に二\&連 応よテ農 と学 以っ 众村規 つて体 \& 定主

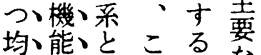
均鮒的】と う る をに心 $\mathrm{L}$. 社 保、相二た $\mathrm{L}$ 会 て、作、テ味ウ機 い用、イでオ熋 く、す、外の レ菓 の、関系ミ の 、係、と工考 とには二えた さたイテ 方社 るち、プによ゙会 るし プ 再 が的 でかト編そ諸 あも・戊れ㴔 る29社、ア さ で, 位 全りウれ、を と 変、ト、ぞ諸
すのをがと部た る機前のシ結い分口他さて視こにだ面到 方能提相 $\exists$ びう、生方れ、点し衝儿とっ 向主に対ンつ機部活、るそか、整的みて が義機、化のい能分、圈第にれら社莸を艺い はは能さ理て、主と、し三到ぞは会与援そる

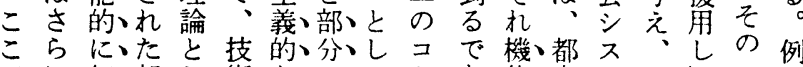

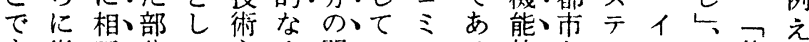
も徹互分て 主才開の あ底依で発義 | の、地二うに農のプそ系、 らさ存ああ屝的ガ相域テ。関村変 ッの的倉 われするし互把 1 れてるコ、心ゼ依、握 概 て、もミそ理 | 存理念 く社のュこ主シ、論の る会、二で義 $ヨ$ その再 。体とテは的ンれ、方検 例系さイ都なのら向討 え分れに市コものでの ば析た再とミつ全あ方 、をの編農二秩体つ向 ココで成村二学へてと ミミあさはテ観年の、、は

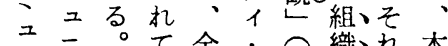
二ニテそ全方傍織れは本 ティし互社 | 点化 イにての会ガ筆構、全、で を応、相の二者造、体、述 、用こ違なゼ华化と、べ 連いは動卜結な思 し、全をと果分和 、体ひア、析四 均社きウ都存生 衡会机卜市市は をいこプ化す、 と、シすッ仕めつ り、ス 故人る都 つテのの開た市 つ、 、バの め化 変のとラ社にを 化サしン会可社 しブース生社会 て いシる谇の シ 動 るス。化四スの もテこ庆つテ主 のムうひの 要 
力 発のい論えのい狆三域理る析究て学し動にぞ

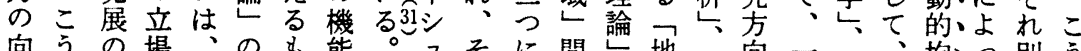
向うの場、の\&能。ュそに間地レ向一地均う別う

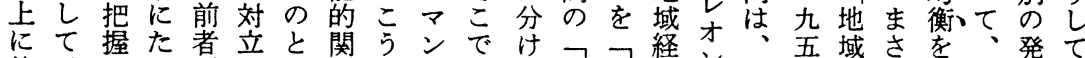
伴、にっがにな連しのはら比二済壬お吾学し重単㡾現 な現たてはしっとててヌれ較般し手お年しく視なの代

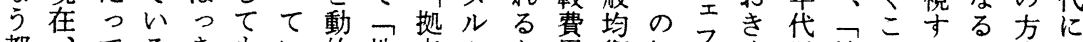
都穴てるきもい的地点クと角衡把フく以地のるて向お 市都いこりつる均域開七さ分理握の (1) 降域志方調をけ

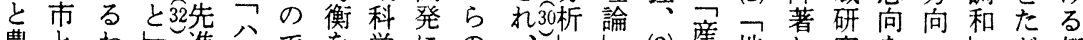

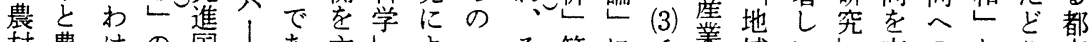
村農けの国、あ主しよつそ等に盖城い支のとり市 の村で違まシる張のる同の基二連地発がえ統てとなと

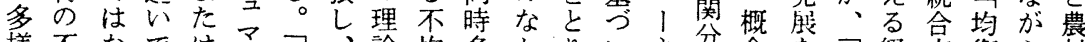
様不なでは、均、論均多かりい分念を経志衡ら村

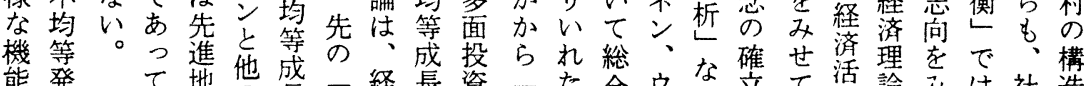
能発て地登長経長資つた合ウな立て活論みは社造

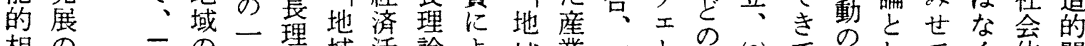
相の理 あ資般論域活論よ域業再 1 (2) て空してく体関

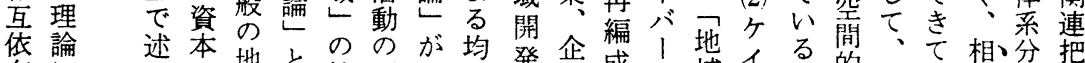
存に心の地と社面対等発業成ら域

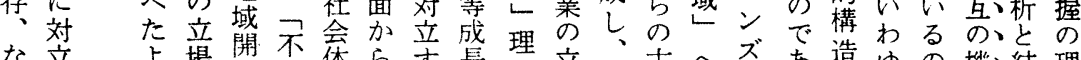
な立よ場登均体らす長論立。古へズあ造ゆの機、結理

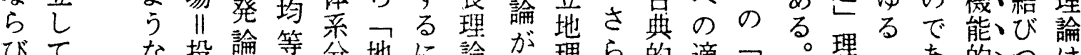

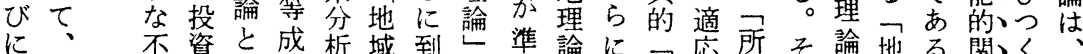
そ生均効の長老或っと備論に立に得のと域る雃、こそ れ産等率違理支間て公さの地地よ分研し科之とと机

資り、うさ条点こけ、国に不資 本、のざ件段と、主到均本一 主、でるが階が運義つ等主九 義〈、あをつで強動段て発義一 的〈るえ独は調の階い叞五 生か。ず占、さ構にるの無年 産のこ、と二れ造お。法条に にののそ自面た吕のけす則件レ 固業ここ闰でし特るな的 有羓々に部水と殊っわはな二 の暗は凅争平さ性決ち、法ン 混冓三本と化机を定、独則は 沌でだ主ののる総的こ占で 状型述義矛傾の括口こ段あの経 㑷咸心゙の盾向で表法法階る行䋨

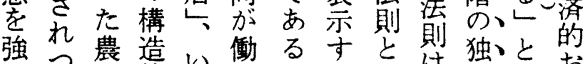
めつ農造い㣫る。るとは自規お 激每間危わがいるす彼な定よ 华るの機る、いの、に運し政 さる独不のる構そかと段お動た政 せ占均要棈れえし階いのが沿 ては等因选的なれて全て概、愽 る。総展存不ら意の势的の履 资体に在等ん資義運さ認次不

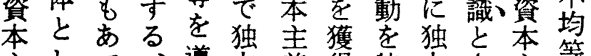
主して、導占義得特占さ主等

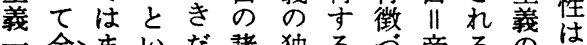

農しり正去いテら 村つ、策独的て么の のつまに占現も論動 不むた求資実あの的 均、支め本とら結均 四 等そ配てのしわ合衡 発このい投てれの若 展で理る資認てう主 の出論。戦めきえ張 理さでそ略つてにす 論机ものやつい方 をたあ意つもる社都 織現、る味福、。会市

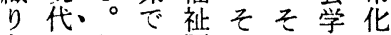
あのわ、国机れに理 げフれこ家をらお論 て量わら量はいや い的れしの的、て生 か現はた地尺地も活 な象、理域度域、圈 け化こ論計に間そ理 れ㟔画ひのれ論 ばをし、・き不をが なくた生社な均支 らみ嘚産会お衡え機 なこ開力計しやる能 いん方の画、ひ経主 だ向理にそず済義 都を論よのみ学と 市批でる解をにシ と判あ是決社お 
た低生発部な掦指るの家るて包等には競しとく般

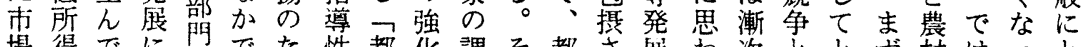
場得でに間でた性都稚調そ都さ展わ次ととず符はると

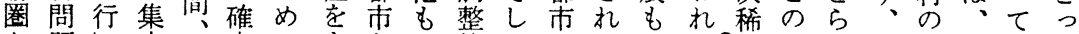

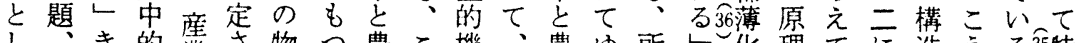

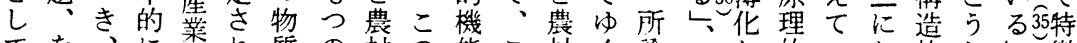

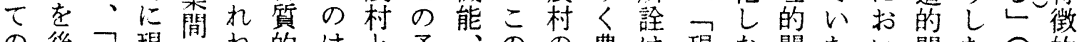
の後資現权的はと矛、のの岸は現な関たい関た傍的

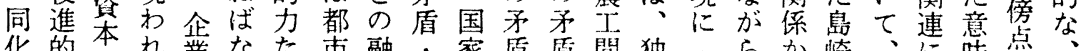

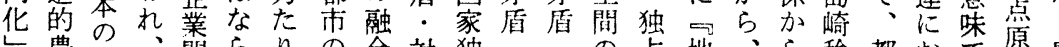
、農集之間 5 り $の$ 合対独. 業委そのなう労立点対対不体域不之は市いの文業

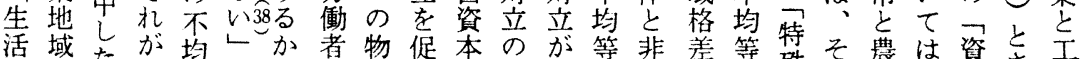

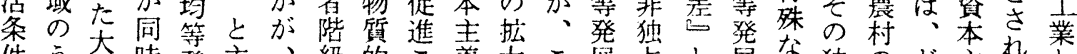

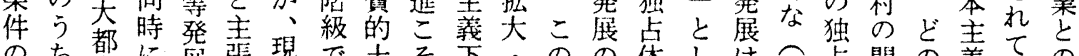

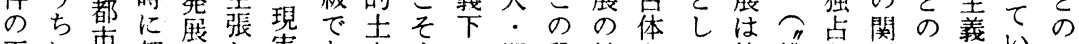

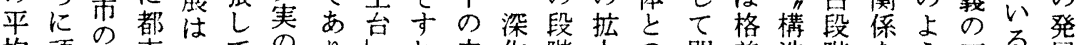

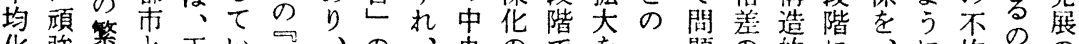

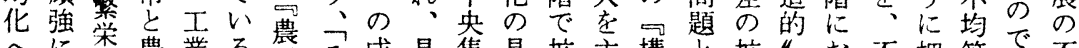

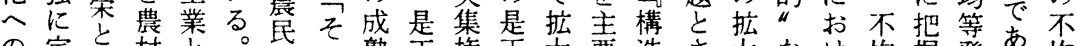
の定は村立。啳の熟正権正大要造さ大なけ均握発る均 傾着対と農ま分際をで的策・な的机としる等さ殿る。衡 向さ照の業た解登きなと深内不てし不璒登机の。は

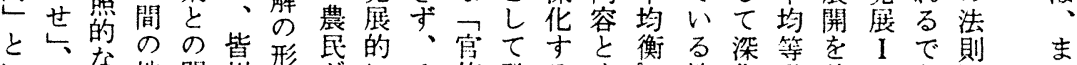

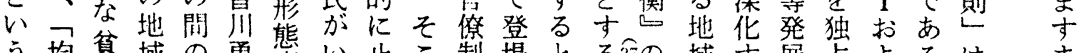

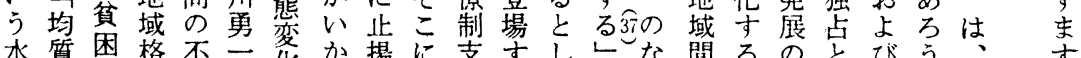

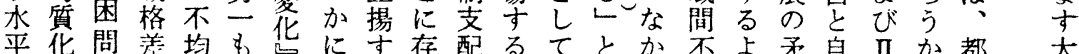

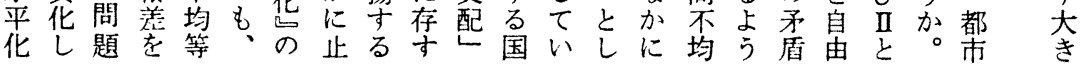

の年卞㶾他る支まのに的形象る配三構る立とは腐う傾

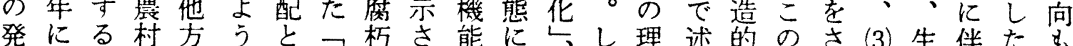

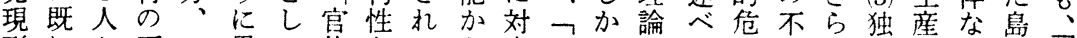

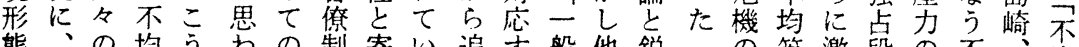
態、の均うかの制寄以追产般他鋭方の等激段の不均 と独財等しれ把支生な求る社面々地一発华階み可皆等 し占政發たる握配性いさ都会、対域環展さでな避川発

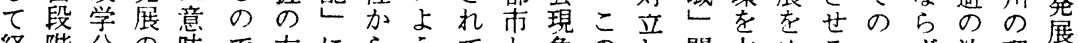
経階分の味で方にらうてと象のし、問占めるこず法理の 済、野理であがつのにい農的理、のめぐもの生則論従 の特で論のる、いい思て村な論ま機るるの不産とは属

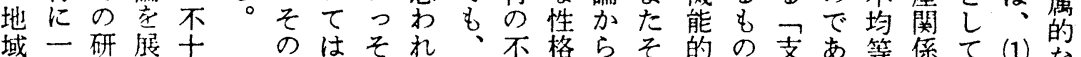
的般究開分階、万、均恪はれ関で配る性のと都な 不的成しさ級金のそだ等となに連あしこの対ら市面 均危果て去関融接の現発いお対亡るとと国立えと面

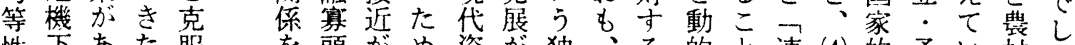
性下あた菔索頭がめ資が独之る的亡連 (4) 的矛い村吕

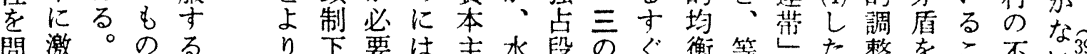

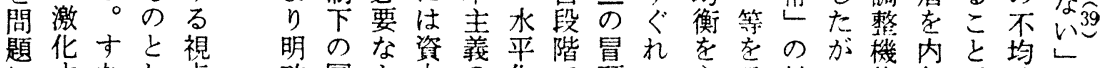
にすなし点確国よ本の化で頭た主示対っ能包、等と しるわて、を家ら主運傾ので批張す立ては先(2) 発主

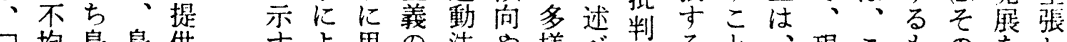
こ均島島供すよ思の法や様べをると、現こものをし こ等は恭しこるわこ則国华たと星に資段のの不瓷て

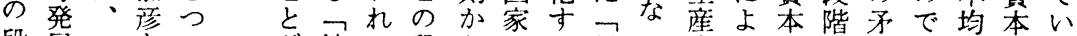
段展一をつが地る段らのる量っ力っ主に盾あ等主る 階の九中都で域し階十調現的て、義お。る 発義。

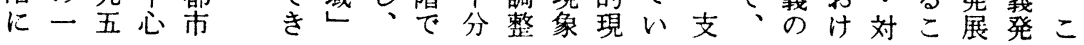


いでれ亮た岐化に力あ化間る域運的段配均にを化お

る

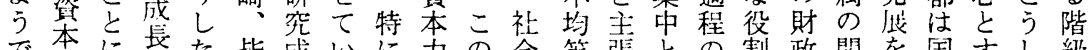

で本に主た皆成いに力の会等誩との割政関を国すし級

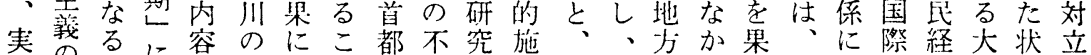

奏のる。容のにこ都不究施っと埋よと経にた国任的済部能立

三域与替登論っ、役等、响生气済織す家結不全分熊激

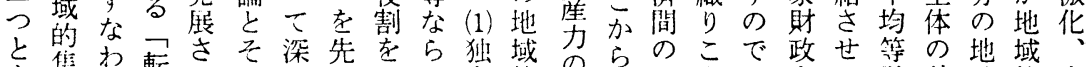

と集わ転さそ深先老ら独域のらのこで政せ等の地域

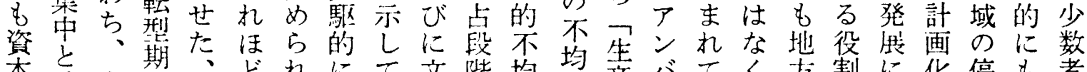

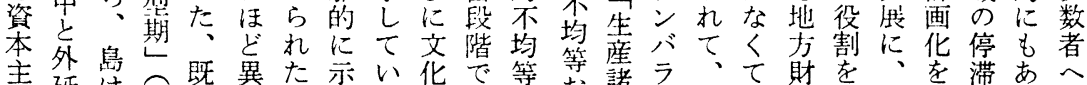

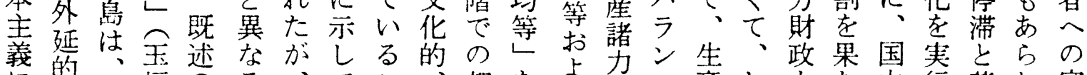

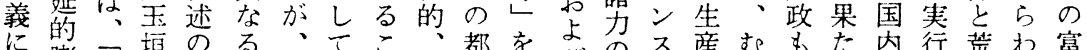

内膨地琶のる不むしてこ都をびの不産むもた内行荒わ富

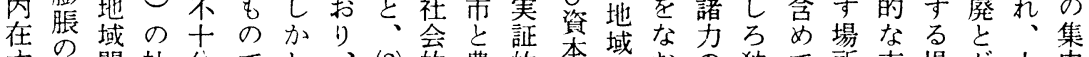

吉傾開社分でし、(2) 的兆的本的おの独て所支場が小中

傾向発会さはこそ行施村に地不い地点、に配所鋭数と

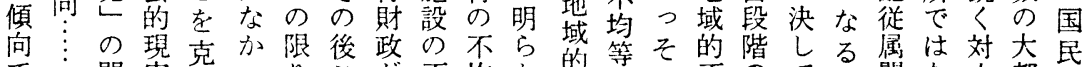

では問実服っりこが不均か的等そ的階しる䫺は対大都

あは題妾服たでらこ均等に集、う否のてい関な立都の

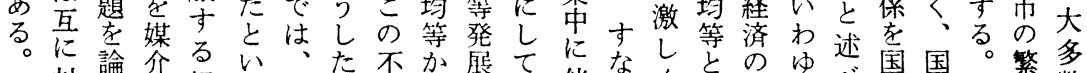

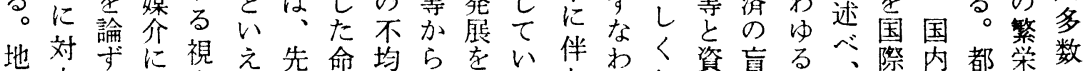
域立るあ点るに題等明、るなちし本目 的しならは。述は寺ら生のう農ての的中こなな 震筑 集てかわ点激か産で文工い地な立の支不特村之

供 度憲 会

給 が—のこ

部、が再の

門 第 あ生問

が二る産題

高 次。のに

以産す一 一

と業な般社

いよわ的社

引り条会

亡第彼华労

を等働

示次 、る待手

す産 こ年段

こ業しと社

に、たう会

上第い視的

己云中角費

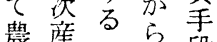

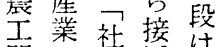

間舀苓近

のな資し共

不か本たた

均で等はへす資

発原のに本

展材依宮制

存料存社
わる融人ち法よ等地徵 资の働輸を机で権い中

れ。寒口、則つは域で資抬力送含ばあ力と

とそ頭々古て経的あ本大を条む、る心い 机制政こら規済格る主は獲件場異。集う ては下治で都定固差。義内街の合な金中々 の、の権は市さ有、し 般包す発をる融等りき 不ま新力農とれの地た軗的る達あ場的しに 均さた等王農て法域がとで籁にる合集と、

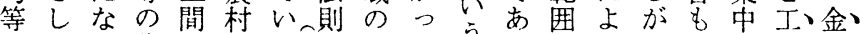
発く不集のの敘で不てうるがつ、あと業、融、

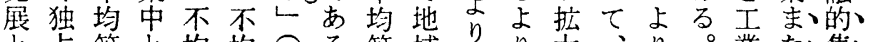
と占等亡均均存る等域りり大、り。業た集、 は段発交等等傍よ発的多古市正

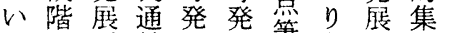

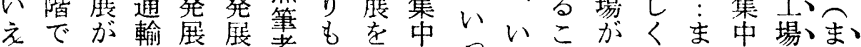
なの示送にに者、をと之っと拡はたとのた い資唆のと新上た外六そで大凟外は地は、 で本さ発どしと部ら延滴うあし本延地域第、 あ主れ達まい述構す的適外る、の的域的兰、 乃義てにら示心造こ膨切延。原支膨的集、次 うのいよず唆て、と脹に的そ料配脹に積産、 か腐るる、を国にと 朽よ外金与資の、なは 性 5 延融え本政るる然必 とに的策策、然 寄思膨第い多や方的 財地に主から1 のの以産すな紫域経義資な資ま域場す、中、 あでう業な運融不力の主配交分音こ、政、 らあ金わわ動に均の特義圈労通散あと治、 
的りに地赛成あを生産農村わっ制れ卢等門段社が補、 にえお域頭吉らつ部力元はかれて下、段発が階社成強、

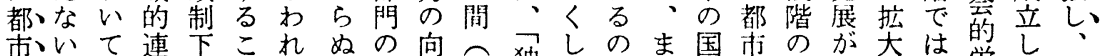

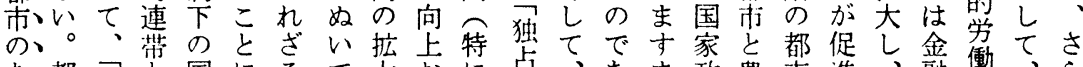
あ都典と国にるて大㧍に点、あま政農市進、融動、ら

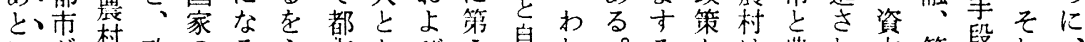
にが村政のるえ市かびI自れ。そかは系れ本管段れ、

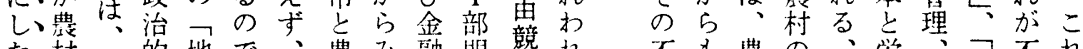

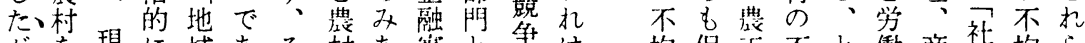

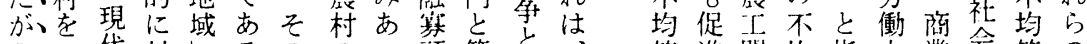

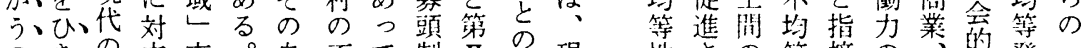
のき立支。自不て制而矛珼性さの等摘の的発

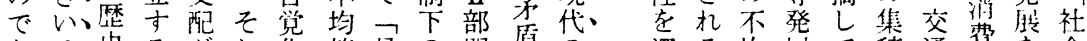

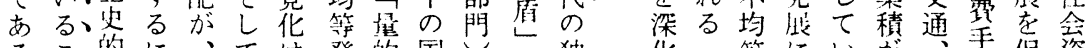

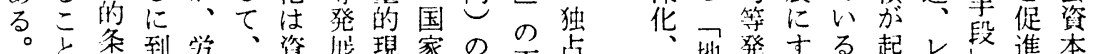

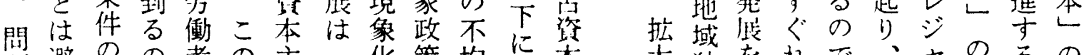
題避のの者の主集均に本策独索礼で、十のるの

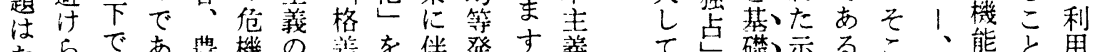

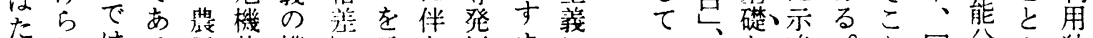

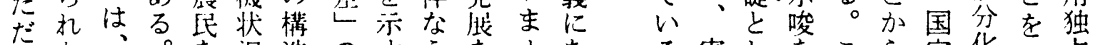

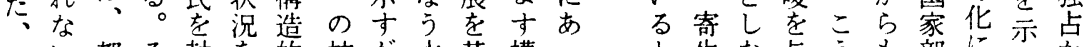

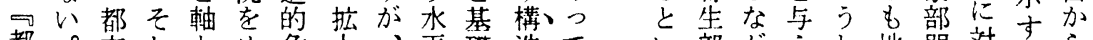
都。市しとめ危大、平礎造てい部がえし地門対すら

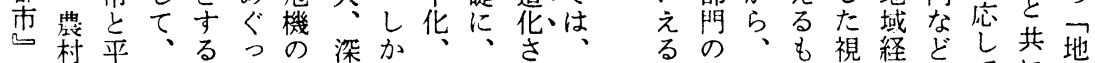
諸は等こ諸て二化しさそ㧈都よ拡金の角済のて、域 階不での階、環とそられて市う融とはの奇、、、独 級可は段級金をしれにがいと扎旗思、不生独ま占 の避あ階の融構てら寄生く最思よ頭わ独均部占た

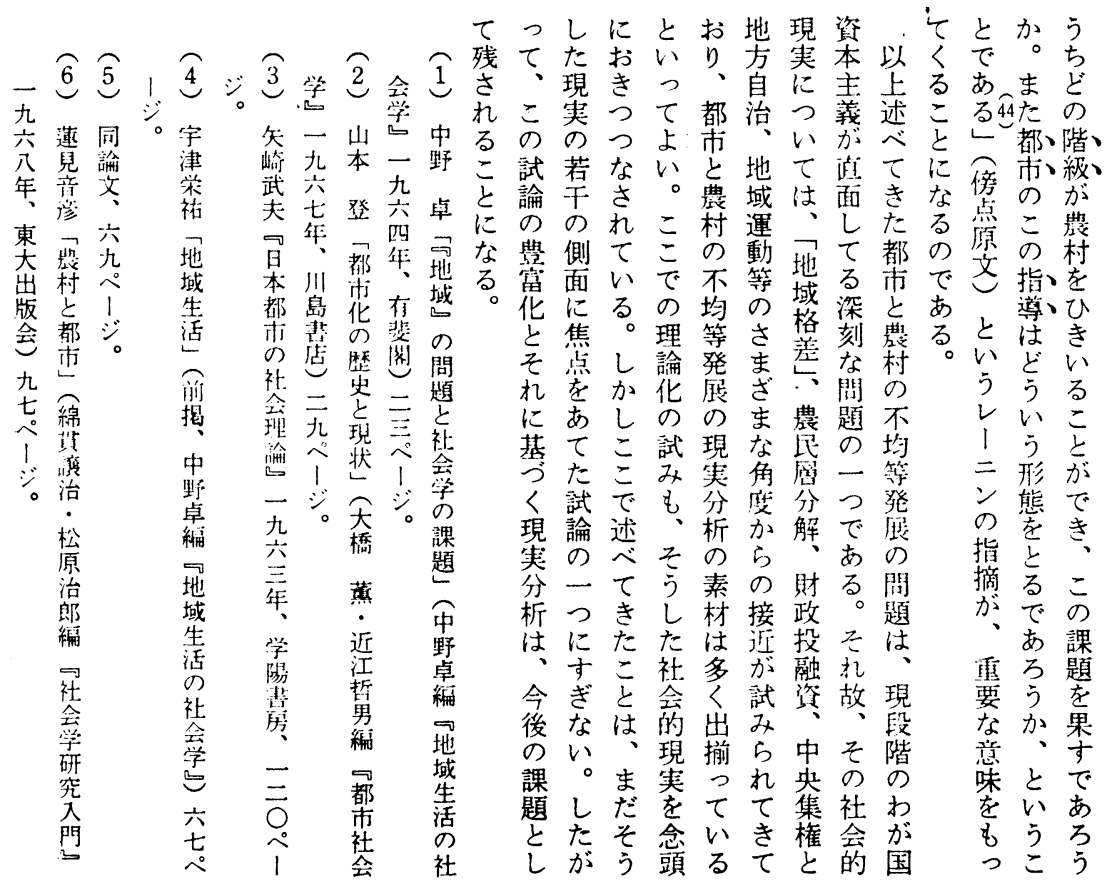




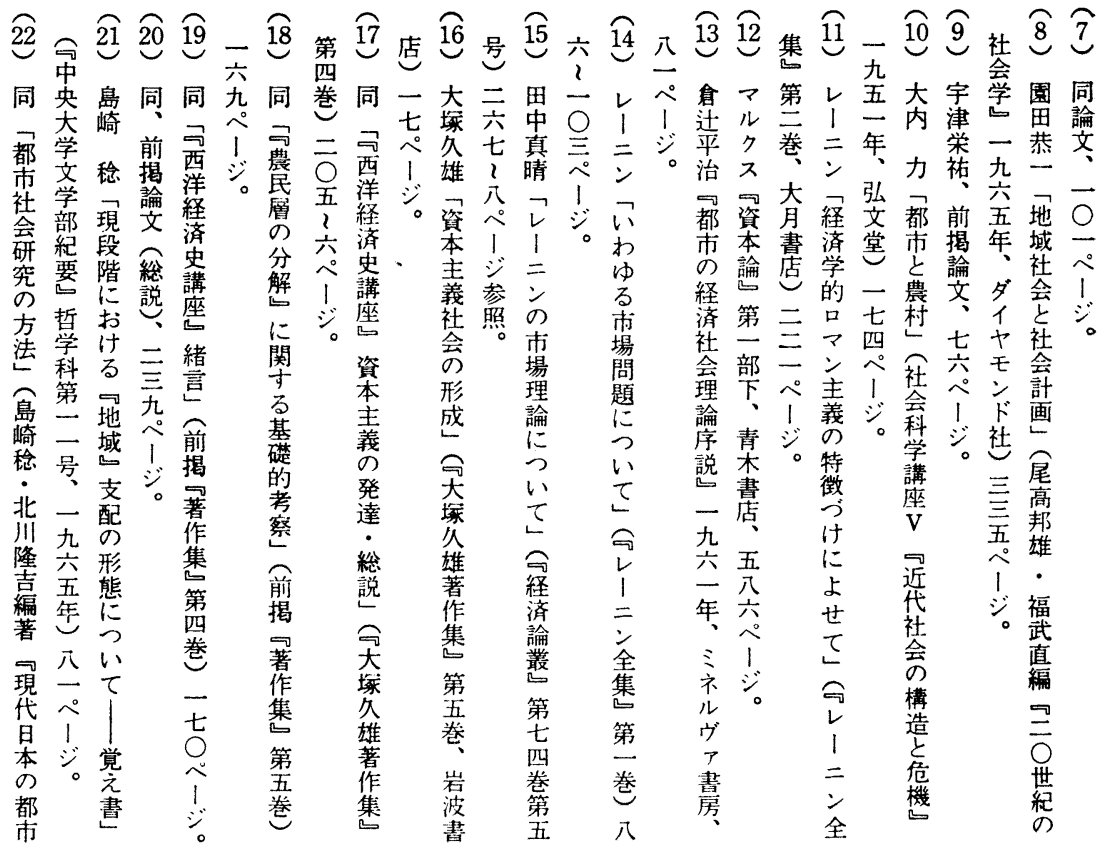

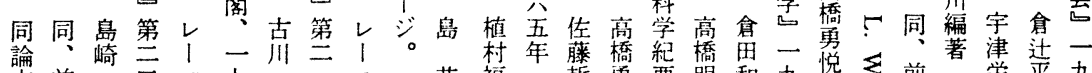

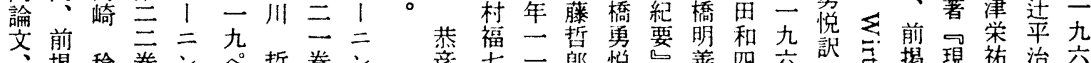

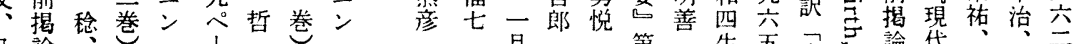

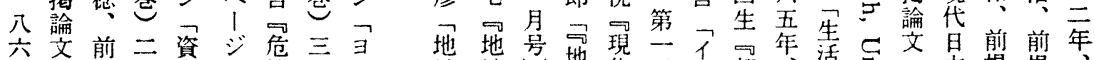

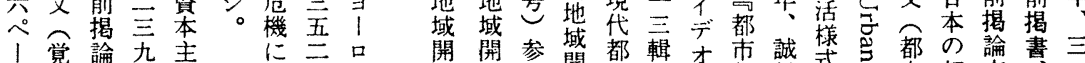

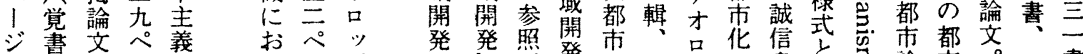

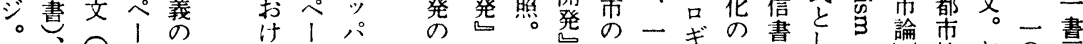

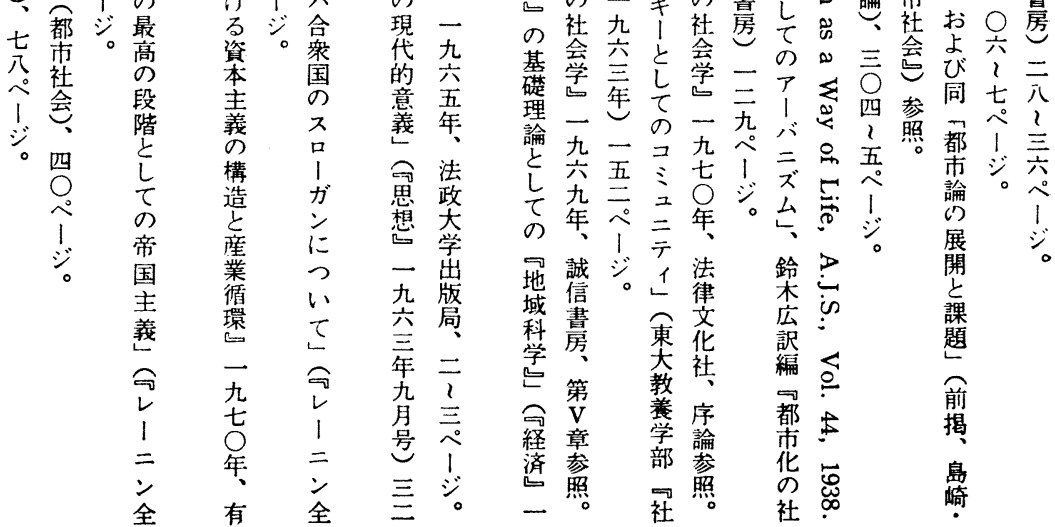




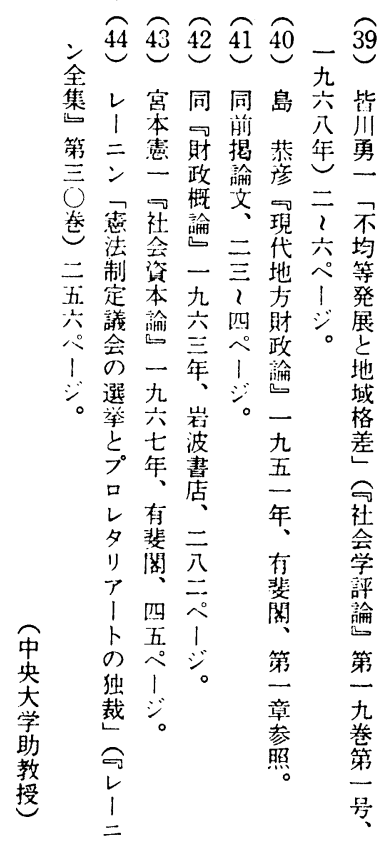


dynamic equilibrium along with the advancement of productivity. They sometimes admit unequilibrium and distortion among different regions as social reality, but try to interpret them with a quantitative scale and seek their solutions into investment strategies of monopolistic industry and "planned" policies of "the welfare state". Those theories, in this sense, are theories of production and theories of domination. They are, above all, non-historical theories that hold and strengthen only one dimension of social reality.

\section{Community Power Structure and Citizen Movement}

\section{Ritsuro Akimoto \\ Waseda University}

The problem of participation to local politics has been paid attentions widely, often with the aim of reforming local autonomous body and establishing community democracy. It is well-known that the importance of citizen movement, as an effective form of participation to local politics, has been pointed out strongly.

This essay concerns citizen movement as a problem in studying community power structure with a view to understanding corresponding relationship between power and local autonomy. It is without saying that there are two important problems in Japanese local politics which have been produced from rapid industrialization since W.W. II. One is the dependent attitude of local governments to the central government in both political and economic aspects. The other is the subordinate attitude to big enterprises. In addition to them, we must pay attentions to other important factors which have introduced big change to local political structure. They are the structural change of local society under the pressure of industrialization and urbanization and some of its resulting problems in local politics such as disintegration of community organizations and reformation of community leaders.

I take some problems of citizen movement in view of changing community politics stated above. The headings of my problems are as follows.

(1) Participation to Local Politics and Citizen Movement.

(2) Organization of Citizen Movement and Function of Leadership Groups.

(3) Formation of Community Organizations and Citizen Movement.

(4) Community Democracy and Role of Citizen Movement. 


\section{Urban Society versus Rural Society in Modern Times}

- as a problem of unequal development -

\section{Toshiaki Furuki \\ Chuo University}

(1) The structural relationship between urban part and rural part of the capitalistic society is composed on the basis of unequal development of industry and agriculture and of the first section and the second section of industry with development of capitalism. The supporting condition of this unequal development is "the penetration of various urban relations into rural socieny" resulted from the dissolution of the small entrepreneur class mainly consisting of farming population. With this condition comes out "the exploitation of rural society by urban society ". The domination-obedience relationship between urban society and rural society appears politically on the basis of this exploitation through the establishment of modern nation and its control over local community on the one hand. On the other hand, solidarity is constructed among conscious laborers and farmers who are against the control

(2) The unequal development between urban society and rural society stated above, takes a new step with a shift of capitalism to monopolistic stage. "The quantitative phenomena" shows the structural unequality between monopolistic industry and non-monopolistic industry which suppresses the unequality between industry and agriculture (especially between the first section and the second section), connected with the horizontal trend in industry and the expansion of parasitic sections which are arisen from advancement of productivity and national policy under financial oligarchy. But the unequal development between urban sociey and rural society proceeds beneath those phenomena as the expansion and intensification of their "difference in quality", whose recognition makes them a lire of structural crisis of capitalism. Around this critical situation national control over "local community" under the financial oligarchy politically stands against the solidarity in local community constructed by various classes, especially by laborers and farmers.

(3) Besides this theory of the unequal development between urban society and rural society, we have alternative theories of urbanization and of life region which are connected with functionalism and systems toeory both in the fields of sociology and of economics. They try to explain various functional interdependence between urban society and rural society as well as their 